\title{
The Seroprevalence of Entrically Transmitted Viral Hepatitis in HCV Infected Thalassemia and Hemophilia Patients in Iran
}

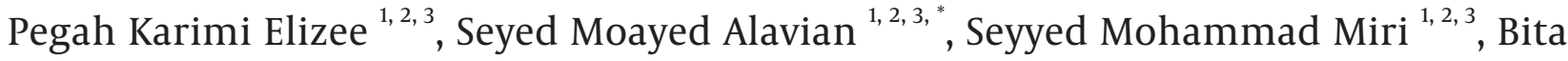 \\ Behnava ${ }^{1,2,3}$, Seyedeh Hoda Alavian ${ }^{4}$, Maryam Keshvari ${ }^{5}$, Mohammad Gholami Fesha- \\ raki $^{6}$, Shima Salimi ${ }^{2,3}$, Leila Mehrnoush ${ }^{2,3}$, Mostafa Shafiei ${ }^{2,3}$ \\ ${ }_{2}^{1}$ Baqiyatallah University of Medical Sciences, Baqiyatallah Research Center for Gastroenterology and Liver Diseases, Tehran, IR Iran \\ ${ }_{3}^{2}$ Middle East Liver Disease Center, Tehran, IR Iran \\ ${ }^{3}$ Tehran Hepatitis Center, Tehran, IR Iran \\ 4 Department of Internal Medicine, Tehran University of Medical Sciences, Tehran, IR Iran \\ 5 Iranian Blood Transfusion Organization research Center, Tehran, IR Iran \\ 6 Biostatistics Department, Tarbiat Modarres University, Tehran, IR Iran \\ *Corresponding author: Seyed-Moayed Alavian, Middle East Liver Disease Center, Tehran, IR Iran, Tel.: +98-2188945186, Fax:+98-2188945188, E-mail: alavian@thc.ir.
}

Received: November 11, 2012; Revised: February 19, 2013; Accepted: April 11, 2013

\begin{abstract}
Background: Hepatitis A and E virus (HAV and HEV) infections are acute and self-limited diseases that usually spread through oral-fecal route. Also, blood transfusion as a possible route of entrically transmitted hepatitis has been suggested. Hemophilia and thalassemia patients are highly at risk of transfusion-transmissible viruses (HBV, HCV, and HIV). Any superimposed infection with other viral hepatitis (in particular hepatitis A) cause active liver failure in hemophilia and thalassemia patients.

Objectives: The aim of this study is to consider seroprevalence of anti HAV and HEV antibodies (Ab) in thalassemia and hemophilia patients with chronic hepatitis $C$ in Iran.

Patients and Methods: In a cross-sectional study and under general census sampling, sera of 219 thalassemia and hemophilia patients infected with HCV were examined in Tehran Hepatitis Center (THC) between 2009 and 2010. Enzyme-linked immunisorbentassey (ELISA) was done to observe anti HAV and HEV IgG Ab. Patients were chosen from all provinces of Iran.

Results: Anti-HAV IgG antibodies were observed more frequently in thalassemia patients $(60 / 64 ; 93.8 \%)$ than in hemophilia patients $(104 / 155 ; 67.1 \%, \mathrm{P}<0.001)$. The seroprevalence of both antibodies increased with age. Among thalassemia patients, there was no significant association between HAV seropositivity and other variables, but in hemophilia group, seropositive patients were significantly older than seronegative group $(\mathrm{P}<0.05)$. Totally, anti HEV Ab $(1 / 64 ; 1.6 \%$ thalassemia and 5/155; 3.2\% hemophilia) was seropositive in six patients. There was no significant association between HEV infection and other variables in thalassemia patients, however, in hemophilia patients, HEV positive ones were significantly older than HEV negative group ( $\mathrm{P}=0.01$ ).

Conclusions: Vaccination of non-immune individuals against HAV infection in high risk groups especially hemophilia and thalassemia patients is recommended. Results did not show any differences about seroprevalence of HEV among Iranian general population.
\end{abstract}

Keywords: Seroprevalence; Hepatitis A; Hepatitis E; Hepatitis C; Thalassemia; Hemophilia; Iran

\section{Background}

Hepatitis A and E virus (HAV and HEV) infections are worldwide public health problems, especially in developing countries. They are enterically transmitted, acute and self-limiting infections of liver which usually spread through oral-fecal route. Risk of catching hepatitis A and E virus increase with age. Although some differences distinguish them from each other, hepatitis E has higher mortality rate and lower prevalence compare to hepatitis A $(1,2)$. From the other point of view, patients with hemophilia (inherited bleeding disorder) and those with thalassemia (poly-transfused disease) are at higher risk of transfusion-transmissible viruses (HBV, HCV and HIV). Due to the higher rate of HCV infection in these two groups, any superimposed infection with other viral hepatitis, especially A could lead to active liver failure (3). In Iran, there are significant number of HCV infected thalassemia and hemophilia patients $(4,5)$,those who are prone to complications of HCV infection, such as cirrhosis, liver failure, and hepatocellular carcinoma (6). Non-immune hemophilia and thalassemia patients against enterically transmitted viral hepatitis, in particular hepatitis A, are more susceptible to liver failure than healthy people. In Iran, epidemiological characteristics of HAV and HEV in-

Implication for health policy/practice/research/medical education:

Study in epidemiology of hepatitis A in the community can help the health policy decision regarding prevention strategies and the article is suitable for internist infection specialist involve family physicians.

Copyright (c) 2013, Ahvaz Jundishapur University of Medical Sciences; Licensee Kowsar Ltd. This is an Open Access article distributed under the terms of the Creative Commons Attribution License (http://creativecommons.org/licenses/by/3.0), which permits unrestricted use, distribution, and reproduction in any medium, provided the original work is properly cited. 
fections are located in a high endemic region; as a result there is not sufficient evidence in this field and we need to fill the ambiguity.

\section{Objectives}

The main aim of this study was to consider the seroprevalence of antibodies against hepatitis $\mathrm{A}$ and $\mathrm{E}$ in thalassemia and hemophilia patients infected with hepatitis $\mathrm{C}$ in Iran. Also, we aimed to determine epidemiological characteristics of HAV and HEV infections among these patients and to plan the most effective preventative strategies against these infections.

\section{Patients and Methods}

Patients were selected from those who had been registered in a national clinical trial project of hepatitis $C$ treatment for Iranian thalassemia and hemophilia patients. All these patients were HCV RNA positive and were more than 12 years old.

In a cross-sectional study, sera of 219 thalassemia and hemophilia patients with HCV infection referred to Tehran Hepatitis Center (THC) between 2009 and 2010 from all provinces of Iran (12 to 76 years old). Sera of the patients were stored at $-20^{\circ} \mathrm{C}$ to perform immunologic stud- ies. Immunoglobulin G (IgG) antibodies against HAV and HEV were detected using Enzyme-linked immunosorbent assay (ELISA) (DIA.PRO, Diagnostic Bioprobes Srl, Italy) according to the manufacturer instructions. The cut-off value was defined using positive and negative control sera that were included in each assay. Samples with opticaldensity (OD) value above the cut-off value considered as positive. All positive samples were retested in duplicate with same enzyme immunoassay to confirm the initial results. The statistical analysis was performed using SPSS (version 18) software. Chi-square test, t-test, and independent sample test were done, and statistical significance was established at P values of $<0.05$. The study was approved by the appropriate ethics committee.

\section{Results}

64 (29.2\%) of HCV infected patients had thalassemia, and 155 of them (70.8\%) had hemophilia. Generally, 32 (14.6\%) of all patients diagnosed with liver cirrhosis. Thalassemia patients were about 5 years younger than hemophilia patients (25.08 \pm 6.46 years old versus $30.63 \pm 11.51$ years old). IgG antibodies against HAV were observed in 164 (74.9\%) of the samples. The antibodies were observed more frequently in thalassemia patients $(60 / 64 ; 93.8 \%)$ than in hemophilia group (104/155; 67.1\%, P < 0.001) (Table 1$)$.

Table 1. Status of Anti-HAV and HEV Antibodies among Thalassemia and Hemophilia Patients

\begin{tabular}{|c|c|c|c|c|c|c|}
\hline & HAV Ab & & & HEV Ab & & \\
\hline & Positive, No. (\%) & negative, No. (\%) & Pvalue $^{\mathrm{a}}$ & Positive, No. (\%) & Negative, No. (\%) & Pvalue \\
\hline Thalassemia & $60(93.8)$ & $4(6.3)$ & 0.000 & $1(1.6)$ & $63(98.4)$ & 0.674 \\
\hline Hemophilia & $104(67.1)$ & $51(32.9)$ & & $5(3.2)$ & $150(96.8)$ & \\
\hline Total & $164(74.9)$ & $55(25.1)$ & & $6(2.7)$ & $213(97.3)$ & \\
\hline
\end{tabular}

${ }^{\mathrm{a}}$ Pvalue is calculated from Chi-square test and is significant $<0.05$

The seroprevalence of anti-HAV antibody increased with age, ranging from $50 \%$ in patients below 20 years, $77.6 \%$ in 20-40 years old patients, and up to $96 \%$ in patients above 40 years old. There was no significant difference in prevalence of anti-HAV antibody according to age groups
$(\mathrm{P}=0.000)$. The seroprevalence of anti-HEV IgG also increased with age, rising from $0 \%$ in patients below 20 years to $12 \%$ in above 40 years group. In addition, there was no significant difference in age groups for prevalence of anti-HEV IgG $(\mathrm{P}=0.009)$ (Table 2$)$.

Table 2. Comparison of Anti-HAV and HEV Antibodies Among Age Groups

\begin{tabular}{|c|c|c|c|c|c|c|}
\hline & HAV Ab & & & HEV Ab & & \\
\hline & Positive, No. (\%) & Negative, No. (\%) & Pvalue $^{a}$ & Positive, No. (\%) & Negative, No.(\%) & Pvalue $^{\mathrm{a}}$ \\
\hline Age & & & 0.000 & & & 0.009 \\
\hline$<\mathbf{2 0}$ & $19(50.0)$ & $19(50.0)$ & & $0(0)$ & $38(100.0)$ & \\
\hline $20-40$ & $121(77.6)$ & $35(22.4)$ & & $3(1.9)$ & $153(98.1)$ & \\
\hline$>40$ & $24(96.0)$ & $1(4.0)$ & & $3(12.0)$ & $22(88.0)$ & \\
\hline
\end{tabular}

${ }^{\mathrm{a}} \mathrm{P}$ value is calculated from Chi-square test and is significant $<0.05$

Among thalassemia patients, there was no significant association between HAV seropositivity and other vari- ables like gender, marital status, region, province, level of education, and mean age (Table 3). But in hemophilia 
group, seropositive patients (mean \pm SD age $=33.88 \pm 11.3$ years old) were significantly older than seronegative patients (mean \pm SD age $=24.00 \pm 8.69$ years old $)(\mathrm{P}<0.01)$. Single subjects in same group had higher prevalence of anti HAV Ab $(\mathrm{P}<0.01)$ also, most seropositive hemophilia patients lived in urban area $(\mathrm{P}=0.03)$. There was not any significant association between HAV seropositivity and history of icterus, addiction, and history of prison ( $\mathrm{P}=$ not significant). The blood interval, history of splenectomy, and severity of liver disease were not related to HAV infection in thalassemia group (data not shown).

Table 3. Demographic Distribution of HAV Seropositivity and Seronegativity Among Thalassemia and Hemophilia Patients Base on Marital Status, Region, Province, Level of Education, and Mean Age of Patients

\begin{tabular}{|c|c|c|c|c|c|c|c|}
\hline & & $\begin{array}{l}\text { Thalassemia } \\
\text { Anti HAV Posi- } \\
\text { tive, No. }(\%)\end{array}$ & $\begin{array}{l}\text { Hemophilia Anti } \\
\text { HAV Negative, } \\
\text { No. (\%) }\end{array}$ & Pvalue $^{a}$ & $\begin{array}{l}\text { Anti HAV Posi- } \\
\text { tive, No. (\%) }\end{array}$ & $\begin{array}{l}\text { Anti HAV } \\
\text { Negative, No. } \\
(\%)\end{array}$ & Pvalue $^{\mathrm{a}}$ \\
\hline \multirow[t]{3}{*}{ Gender } & & & & 1.00 & & & 0.75 \\
\hline & Male & $30(50)$ & $2(50)$ & & $95(91.3)$ & $48(94.1)$ & \\
\hline & Female & $30(50)$ & $2(50)$ & & $9(8.7)$ & $3(5.9)$ & \\
\hline \multirow[t]{3}{*}{ Marital status } & & & & 0.42 & & & 0.000 \\
\hline & Single & $53(88.3)$ & $3(75)$ & & $42(40.4)$ & $42(82.4)$ & \\
\hline & Married & $7(11.7)$ & $1(25)$ & & $62(59.6)$ & $9(17.6)$ & \\
\hline \multirow[t]{3}{*}{ Region } & & & & 1.00 & & & 0.03 \\
\hline & Urban & $51(85)$ & $4(100)$ & & $83(79.8)$ & $47(92.2)$ & \\
\hline & Rural & $9(15)$ & $0(0)$ & & $21(20.2)$ & $4(7.8)$ & \\
\hline \multirow[t]{5}{*}{ Education } & & & & 0.62 & & & 0.87 \\
\hline & Illiterate & $0(0)$ & $0(0)$ & & $5(4.8)$ & $2(3.9)$ & \\
\hline & $\begin{array}{l}\text { Under } \\
\text { diploma }\end{array}$ & $23(38.3)$ & $1(25)$ & & 35 (33.7) & $19(37.3)$ & \\
\hline & $\begin{array}{l}\text { Diploma or } \\
\text { Bachelor of } \\
\text { college }\end{array}$ & $31(51.7)$ & $2(50)$ & & $51(49)$ & $22(43.1)$ & \\
\hline & $\begin{array}{l}\text { Bachelor } \\
\text { of science } \\
\text { (BS) and } \\
\text { more }\end{array}$ & $6(10)$ & $1(25)$ & & $13(12.5)$ & $8(15.7)$ & \\
\hline \multirow{7}{*}{$\begin{array}{l}\text { Iran's provinces } \\
\text { located in: }\end{array}$} & & & & 0.93 & & & 0.39 \\
\hline & Capital & $11(18.3)$ & $1(25)$ & & $29(27.9)$ & $16(31.4)$ & \\
\hline & North & $20(33.3)$ & $1(25)$ & & $9(8.7)$ & $9(7.6)$ & \\
\hline & South & $13(21.7)$ & $1(25)$ & & $9(8.7)$ & $6(11.8)$ & \\
\hline & East & $4(6.7)$ & $0(0)$ & & $11(10.6)$ & $5(9.8)$ & \\
\hline & West & $5(8.3)$ & $0(0)$ & & $23(22.1)$ & $6(11.8)$ & \\
\hline & Center & $7(11.7)$ & $1(25)$ & & $23(22.1)$ & $9(17.6)$ & \\
\hline Mean \pm SD age & & $25.15 \pm 6.57$ & $24.00 \pm 5.22$ & $0.73^{\mathrm{b}}$ & $33.88 \pm 11.3$ & $24.00 \pm 8.69$ & $0.000^{\mathrm{b}}$ \\
\hline
\end{tabular}

Six patients (2.7\%) had seropositive HEV IgG antibody (one thalassemia, and 5 hemophilia patients) (Table 1). Neither gender, age, marital status nor province had significant association with HEV infection in both groups.
Among hemophilia patients, HEV positive ones (mean \pm SD age: $42.80 \pm 19.94$ years old) were significantly older than negative ones (mean \pm SD age: $30.22 \pm 11.00$ years old $)(P=0.01)$ (Table 4$)$. 
Karimi Elizee P et al.

\begin{tabular}{|c|c|c|c|c|c|c|c|}
\hline & & $\begin{array}{l}\text { Thalassemia } \\
\text { HEV Ab Positive }\end{array}$ & $\begin{array}{l}\text { Hemophilia HEV } \\
\text { Ab Negative }\end{array}$ & P-value $^{a}$ & $\begin{array}{l}\text { HEV Ab Posi- } \\
\text { tive }\end{array}$ & $\begin{array}{l}\text { HEV Ab Nega- } \\
\text { tive }\end{array}$ & Pvalue $^{a}$ \\
\hline \multirow[t]{3}{*}{ Gender } & & & & 1.00 & & & 1.00 \\
\hline & Male & $0(0)$ & $32(50.8 \%)$ & & $5(100 \%)$ & $138(92)$ & \\
\hline & Female & $1(100)$ & $31(49.2 \%)$ & & $0(0 \%)$ & $12(8)$ & \\
\hline \multirow[t]{3}{*}{ Marital status } & & & & 0.12 & & & 0.13 \\
\hline & Single & $0(0)$ & $56(88.9)$ & & $1(20)$ & $83(55.3)$ & \\
\hline & Married & $1(100)$ & $7(11.1)$ & & $4(80)$ & $67(44.7)$ & \\
\hline \multirow[t]{3}{*}{ Region } & & & & 1.00 & & & 1.00 \\
\hline & Urban & $1(100)$ & $54(85.7)$ & & $5(100)$ & $125(83.3)$ & \\
\hline & Rural & $0(0)$ & $9(14.3)$ & & $0(0)$ & $25(16.7)$ & \\
\hline \multirow[t]{5}{*}{ Education } & & & & 0.42 & & & 0.03 \\
\hline & Illiterate & $0(0)$ & $0(0)$ & & $1(20)$ & $6(4)$ & \\
\hline & $\begin{array}{l}\text { Under } \\
\text { diploma }\end{array}$ & $1(100)$ & $23(36.5)$ & & $4(80)$ & $50(33.3)$ & \\
\hline & Diploma & $0(0)$ & $33(52.4)$ & & $0(0)$ & $73(48.7)$ & \\
\hline & $\begin{array}{l}\text { BS and } \\
\text { more }\end{array}$ & $0(0)$ & $7(11.1)$ & & $0(0)$ & $21(14)$ & \\
\hline \multirow{7}{*}{$\begin{array}{l}\text { Iran's prov- } \\
\text { inces located } \\
\text { in: }\end{array}$} & & & & 0.83 & & & 0.21 \\
\hline & Capital & $0(0)$ & $12(19)$ & & $0(0)$ & $45(30)$ & \\
\hline & North & $1(100)$ & $20(31.7)$ & & $2(40)$ & $16(10.7)$ & \\
\hline & South & $0(0)$ & $14(22.2)$ & & $0(0)$ & $15(10)$ & \\
\hline & East & $0(0)$ & $4(6.3)$ & & $0(0)$ & $16(10.7)$ & \\
\hline & West & $0(0)$ & $5(7.9)$ & & $1(20)$ & 28 (18.7) & \\
\hline & Center & $0(0)$ & $8(12.7)$ & & $2(40)$ & $30(20)$ & \\
\hline Mean \pm SD age & & 36.00 & $24.90 \pm 6.36$ & $0.08^{\mathrm{b}}$ & $42.80 \pm 19.94$ & $30.22 \pm 11.00$ & $0.01^{\mathrm{b}}$ \\
\hline
\end{tabular}

a $\mathrm{P}$-value is calculated from Chi-square test and $\mathrm{P}<0.05$ was considered significant

$\mathrm{b}_{\mathrm{P} \text {-value is calculated from Independent Samples Test and is significant }<0.05}$

\section{Discussion}

Thalassemia and hemophilia patients are at risk of viral hepatitis due to their needs to blood products. Most of them have chronic liver disease (CLD) such as chronic hepatitis C. The clinical courses of HAV and HEV infections are more severe in the patients with CLD (3, 7-9). Basically, patients with HCV infection are more exposed to HAV associated fulminant hepatic failure than those patients without CLD. Vento et al. found that $41.2 \%$ of patients with acute HAV super-infection had acute liver failure with a mortality rate of $35.3 \%$ (7).

In our study, the overall seroprevalence of IgG antibody against HAV and HEV in Iranian thalassemia and hemophilia patients were $74.9 \%$ and $2.7 \%$, respectively. The seroprevalence of anti HAV antibody was significantly higher in thalassemia than hemophilia patients (93.8\% and 67.1\% respectively). Findings indicate that more thalassemia patients with HCV had already been exposed to HAV, and consequently had natural acquired immunity against it. In Iranian vaccination program, preventive immunization against HAV is not mandatory, however, it should be considered in non-immune hemophilia and thalassemia patients. Life of poly-transfused thalassemia patients depends on various factors including blood intervals, ferritin levels, and genetic characteristics (4).

Immune deficiency attributed to multiple transfusions and iron overload (10) which could predispose thalassemia patients to HAV infection. No data exists that immune deficiency predispose to HAV infection (11); this seems to be a probable reason for the fact that multitransfusion influences on getting HAV infection. Another possibility is that in thalassemia patients anti HAV IgG might have been transferred passively by means of transfusions and not the expression of actively acquired immunity (11). In addition, high concentration of antibod- 
ies in plasma preparations of multiple donors assists the passive transmission of antibodies in hemophilia patients (11). In overall, potential transfusion of HAV-specific antibodies to the recipient of multiple blood units, and rising seroprevalence to HAV with age significantly reduce risk of post-transfusion hepatitis A.

Most of our statistical populations were hemophilia patients (70.8\%). As this disease is $\mathrm{x}$-linked, $79.9 \%$ of all patients were male who could superimpose our results (76.2\% of seropositive cases were male) in opposite of some related studies $(12,13)$ but similar to this study in Thailand (14). In addition, thalassemia patients were 5 years younger than hemophilia patients with higher prevalence of HAV infection. As risk of HAV infection increases with age (15), it is suggested to think about vaccination against HAV in childhood. Geographic distribution was not related to seroprevalence of HAV; main location of the project was in Tehran thus we could not determine the exact role of residency area in the study.

In different countries, anti-HAV IgG antibody seroprevalence reported in the range of $40-70 \%$ among patients with hemophilia (16-19). In Iran, it is not known how many of these patients are anti-HAV IgG antibody seroprevalence. However, in healthy populations was determined to be different across regions of Iran. Recently published article reported that anti-HAV IgG antibody seroprevalence in Tehran is 90\% (20), in northern part of the country is ranging from $19.20 \%$ in Savadkoh (21),38.9\% in Sari (12) to $98.6 \%$ in Golestan(22), in Fars $88.2 \%$ (23), and among HCV patients in Isfahan is $94.9 \%$ (24).

In addition, some outbreaks of acute hepatitis A observed in Europe, USA, and South Africa among these patients in the early nineties. The patients receiving clotting factor concentrate, particularly products inactivated by solvent-detergent which was ineffective against nonlipid enveloped viruses such as HAV (25-30). In developed countries, hepatitis A vaccine is recommended for HAV seronegative people with clotting disorders, and those with CLD $(31,32)$. On the other hand, some effective examinations such as blood-donor screening, viral inactivation of plasma-derived products, and development of recombinant clotting factors are used to reduce viral exposure (31). Several studies that were done in Japan reported high prevalence of HAV and HEV infection among hemophilia patients compare to healthy individual (control group) $(33,34)$.

As Iran is located in the endemic area of HEV, (35) a few suspected outbreaks of HEV infection were observed in Lordegan (Southeast of Iran) in 1992. Unsanitary sewage disposal with secondary contamination of drinking water was reason for outbreak of HEV infection (36). Like hepatitis A, the seroprevalence of anti-HEV IgG in healthy Iranian populations was demonstrated to be different across regions of Iran, ranging from $2.3 \%$ in northern region (37), 3.8\% in Isfahan (38), 7.8\% in Tabriz (39), 8.5\%-11.5\% in southern region $(40,41)$ and $9.3 \%$ in Nahavand $(42)$. Interestingly HEV seroprevalence was reported $30.8 \%$ in kid- ney transplant recipients (43).

Our results were similar to seroprevalence of Iranian general population, this indicates that blood products cannot be a transmission way for Iranian thalassemia and hemophilia. Contradictory with our data, researchers in a study in Saudi Arabia proposed higher prevalence of HEV among thalassemia children (10.7\%) (44). Toyoda et al. reported $16.3 \%$ HEV seropositivity among hemophilia patients. They also suggested that the parenteral transmission of HEV may have occurred in Japanese patients with hemophilia via non-virus-inactivated coagulation factors (34). Other studies in different countries showed lower HEV seropositivity among hemophilia patients (4548) than Japan.

In conclusion, vaccination of non-immune individuals against HAV infection in high risk groups, especially hemophilia and thalassemia patients are recommended. About seroprevalence of $\mathrm{HEV}$, our results did not show any differences with Iranian general population.

\section{Acknowledgements}

We acknowledge all respected colleagues in MELD center and THC.

\section{Authors' Contribution}

Pegah Karimi Elizee wrote the draft of the article and reanalyzed, Seyed-Moayed Alavian and Seyyed-Mohammad Miri designed the idea and edited the final article. Seyedeh-Hoda Alavian gathered the data. Mohammad Gholami Fesharaki analyzed the data, and other authors contributed in the clinic and visited the patients.

\section{Financial disclosure}

The authors declare that they have no conflicts of interest relevant to this manuscript.

\section{Funding/Support}

Funding of the current research is provided by MELD Center and THC.

\section{References}

1. Wasley A, Feinstone SM, Bell BP, 7th . hepatitis A virus. In: Wasley A, Feinstone SM, Bell BP, 7th , editors.Mandell, Douglas, and Bennett's Principles and Practice of Infectious Diseases .Churchill Livingstone Elsevier; 2010. p. 2367-89.

2. Anderson DA, 7th . Hepatitis E virus. In: Anderson DA, 7th editors.Mandell, Douglas, and Bennett's Principles and Practice of Infectious Diseases .Churchill Livingstone Elsevier;2010. p. 2411-23.

3. Koff RS. Risks associated with hepatitis A and hepatitis B in patients with hepatitis C. JClin Gastroenterol. 2001;33(1):20-6.

4. Alavian SM, Miri SM, Keshvari M, Elizee PK, Behnava B, Tabatabaei SV, et al. Distribution of hepatitis $C$ virus genotype in Iranian multiply transfused patients with thalassemia. Transfusion. 2009;49(10):2195-9.

5. Keshvari M, Alavian SM, Behnava B, Miri SM, Elizee PK, Tabatabaei $\mathrm{SV}$, et al. Distribution of hepatitis $\mathrm{C}$ virus genotypes in iranian patients with congenital bleeding disorders. Iran Red Crescent Med J. 2010;12(6):608-14 
6. Alavian SM, Adibi P, Zali MR. Hepatitis C virus in Iran: Epidemiology of an emerging infection. Arch Iranian Med. 2005;8:84-90.

7. Vento S, Garofano T, Renzini C, Cainelli F, Casali F, Ghironzi G et al. Fulminant hepatitis associated with hepatitis A virus superinfection in patients with chronic hepatitis C. N Engl J Med. 1998;338(5):286-90.

8. Cho HC, Paik SW, Kim YJ, Choi MS, Lee JH, Koh KC, et al. Seroprevalence of anti-HAV among patients with chronic viral liver disease. World J Gastroenterol. 2011;17(2):236-41.

9. Atiq M, Shire NJ, Barrett A, Rouster SD, Sherman KE, Shata MT. Hepatitis E virus antibodies in patients with chronic liver disease. Emerg Infect Dis. 2009;15(3):479-81.

10. Farmakis D, Giakoumis A, Polymeropoulos E, Aessopos A. Pathogenetic aspects of immune deficiency associated with beta-thalassemia. Med Sci Monit. 2003;9(1):RA19-22.

11. Siagris D, Kouraklis-Symeonidis A, Konstantinidou I, Christofidou M, Starakis I, Lekkou A, et al. Prevalence of anti-HAV antibodies in multitransfused patients with beta-thalassemia. World $J$ Gastroenterol. 2008;14(10):1559-63.

12. Alian S, Ajami A, Ghasemian R, Yadegarinia D. Age-specific seroprevalence of hepatitis A in Sari, northern Islamic Republic of Iran. East Mediterr Health J. 2011;17(10):754-8.

13. Vilibic-Cavlek T, Kucinar J, Ljubin-Sternak S, Kolaric B. Seroepidemiology of hepatitis a in the croatian population. Hepat Mon. 2011;11(12):997-9.

14. Luksamijarulkul P, Sujirarat D, Charupoonphol P. Risk Behaviors, Occupational Risk and Seroprevalence of Hepatitis B and A Infections among Public Cleansing Workers of Bangkok Metropolis . Hepat Mon. 2008;8(1):35-40.

15. Ghorbani GA. Is evaluation of hepatitis a immunity required or not? Hepat Mon. 2011;11(12):955-7.

16. Scaraggi FA, Perricci A, Petronelli M, Lomuscio S, De Mitrio V, Schiraldi O. Prevalence of serum IgG antibodies to hepatitis A virus in Italian haemophiliacs. Lancet. 1992;339(8807):1486-7.

17. Mosley JW. Has hepatitis A virus been transmitted by clotting factor concentrates among hemophiliacs in the United States? Vox Sang. 1994;67 Suppl 4:12-5.

18. Kreuz W, Klarmann D, Auerswald G, Auberger K, Gurtler L, Rabenau $\mathrm{H}$, et al. Absence of hepatitis A after treatment with pasteurised factor VIII concentrates in children with haemophilia A and von Willebrand disease. Lancet. 1993;341(8842):446.

19. Innis BL, Snitbhan R, Kunasol P, Laorakpongse T, Poopatanakool W, Kozik CA, et al. Protection against hepatitis A by an inactivated vaccine. JAMA. 1994;271(17):1328-34.

20. Mohebbi SR, Rostami Nejad M, Tahaei SM, Pourhoseingholi MA Habibi M, Azimzadeh P, et al. Seroepidemiology of hepatitis A and $E$ virus infections in Tehran, Iran: a population based study. Trans R Soc Trop Med Hyg. 2012;106(9):528-31.

21. Saffar MJ, Abedian O, Ajami A, Abedian F, Mirabi AM, Khalilian AR, et al. Age-specific seroprevalence of anti-hepatitis a antibody among 1-30 years old population of savadkuh, mazandaran, iran with literature review. Hepat Mon. 2012;12(5):326-32.

22. Ghadir MR, Jafari E, Rezvan H, Amini-Kafiabad S, Vaeze-Javadi M, Pourshams A. Hepatitis A and E in the east of Golestan province. J Med Council I.R.I. 2007;25(1):34-8.

23. Taghavi SA, Hosseini Asl MK, Talebzadeh M, Eshraghian A. Seroprevalence study of hepatitis A virus in Fars province, southern Iran. Hepat Mon. 2011;11(4):285-8.

24. Shoaei P, Zeidabadinejad L, Hassannejad R, Ataei B, Yaran M, Kassaian N, et al. Seroprevalence of Hepatitis A in Patients with Chronic Hepatitis C in Isfahan Province. Int J Prev Med. 2012;3(Suppl1):S102-6.

25. Johnson Z, Thornton L, Tobin A, Lawlor E, Power J, Hillary I, et al An outbreak of hepatitis A among Irish haemophiliacs. Int J Epidemiol.1995;24(4):821-8.

26. Soucie JM, Robertson BH, Bell BP, McCaustland KA, Evatt BL. Hepatitis A virus infections associated with clotting factor concentrate in the United States. Transfusion.1998;38(6):573-9.

27. Brackmann HH, Oldenburg J, Eis-Hubinger AM, Gerritzen A Hammerstein U, Hanfland P. Hepatitis A virus infection among the hemophilia population at the Bonn Hemophilia Center. Vox Sang. 1994;67 Suppl 1:3-7
28. Mannucci PM, Gdovin S, Gringeri A, Colombo M, Mele A, Schinaia $\mathrm{N}$, et al. Transmission of hepatitis A to patients with hemophilia by factor VIII concentrates treated with organic solvent and detergent to inactivate viruses. The Italian Collaborative Group Ann Intern Med.1994;120(1):1-7.

29. Kedda MA, Kew MC, Cohn RJ, Field SP, Schwyzer R, Song E, et al An outbreak of hepatitis A among South African patients with hemophilia: evidence implicating contaminated factor VIII concentrate as the source. Hepatology. 1995;22(5):1363-7.

30. Normann A, Graff J, Gerritzen A, Brackmann HH, Flehmig B. Detection of hepatitis A virus RNA in commercially available factor VIII preparation. Lancet. 1992;340(8829):1232-3.

31. Steele M, Cochrane A, Wakefield C, Stain AM, Ling S, Blanchette V, et al. Hepatitis A and B immunization for individuals with inherited bleeding disorders. Haemophilia. 2009;15(2):437-47.

32. Chambost H, Doncarli A, Bertrand MA, Briquel ME, Gay V, Pincemaille $\mathrm{O}$, et al. Implementation of a hepatitis A prevention policy in haemophiliacs: results from the French cohort. Haemophilia. 2007;13(6):712-21

33. Hayashi K, Fukuda Y, Nakano I, Katano Y, Nagano K, Yokozaki S, et al. Infection of hepatitis A virus in Japanese haemophiliacs. Infect. 2001;42(1):57-60.

34. Toyoda H, Honda T, Hayashi K, Katano Y, Goto H, Kumada T, et al. Prevalence of hepatitis E virus IgG antibody in Japanese patients with hemophilia. Intervirology. 2008;51(1):21-5.

35. Aggarwal R, Naik S. Epidemiology of hepatitis E: current status.J Gastroenterol Hepatol. 2009;24(9):1484-93.

36. Ariyegan M, Amini S. Hepatitis E epidemic in Iran. J Med Council I.R. Irn . 1998;15:139-43.

37. Saffar MJ, Farhadi R, Ajami A, Khalilian AR, Babamahmodi F, Saffar H. Seroepidemiology of hepatitis E virus infection in 2-25-year-olds in Sari district, Islamic Republic of Iran. East Mediterr Health J. 2009;15(1):136-42.

38. Ataei B, Nokhodian Z, Javadi AA, Kassaian N, Shoaei P, Farajzadegan Z, et al. Hepatitis E virus in Isfahan Province: a populationbased study. Int J Infect Dis. 2009;13(1):67-71.

39. Taremi M, Gachkar L, MahmoudArabi S, Kheradpezhouh M Khoshbaten M. Prevalence of antibodies to hepatitis E virus among male blood donors in Tabriz, Islamic Republic of Iran East Mediterr Health J. 2007;13(1):98-102.

40. Assarehzadegan MA, Shakerinejad G, Amini A, Rezaee SA. Seroprevalence of hepatitis E virus in blood donors in Khuzestan Province, southwest Iran. Int JInfect Dis. 2008;12(4):387-90.

41. Shamsizadeh A., Nikfar R., Makvandi M., Shamsizadeh N. . Seroprevalence of Hepatitis E Virus Infection in Children in the Southwest of Iran. Hepat Mon. 2009;9(4):261-4.

42. Taremi M, Mohammad Alizadeh AH, Ardalan A, Ansari S, Zali MR. Seroprevalence of hepatitis E in Nahavand, Islamic Republic of Iran: a population-based study. East Mediterr Health J 2008;14(1):157-62.

43. Rostamzadeh Khameneh Z, Sepehrvand N, Masudi S. Seroprevalence of Hepatitis E among Iranian Renal Transplant Recipients. Hepat Mon. 2011;11(8):646-51.

44. al-Fawaz I, al-Rasheed S, al-Mugeiren M, al-Salloum A, al-Sohaibani M, Ramia S. Hepatitis E virus infection in patients from Saudi Arabia with sickle cell anaemia and beta-thalassemia major: possible transmission by blood transfusion. J Viral Hepat. 1996;3(4):203-5.

45. Mannucci PM, Gringeri A, Santagostino E, Romano L, Zanetti A Low risk of transmission of hepatitis E virus by large-pool coagulation factor concentrates. Lancet. 1994;343(8897):597-8.

46. Klarmann D, Kreuz W, Kornhuber B. Low prevalence of hepatitis E virus antibodies in hepatitis $C$ virus-positive patients with coagulation disorders. Transfusion. 1995;35(11):969-70.

47. Zaaijer HL, Mauser-Bunschoten EP, ten Veen JH, Kapprell HP, Kok M, van den Berg HM, et al. Hepatitis E virus antibodies among patients with hemophilia, blood donors, and hepatitis patients. JMed Virol. 1995;46(3):244-6.

48. Barzilai A, Schulman S, Karetnyi YV, Favorov MO, Levin E, Mendelson E, et al. Hepatitis E virus infection in hemophiliacs. J Med Virol. 1995;46(2):153-6. 